\title{
LATTICE-MATCHED EPITAXIAL GaInAsSb/GaSb THERMOPHOTOVOLTAIC DEVICES
}

\author{
G. Charache, C. A. Wang, et. al.
}

May 1997

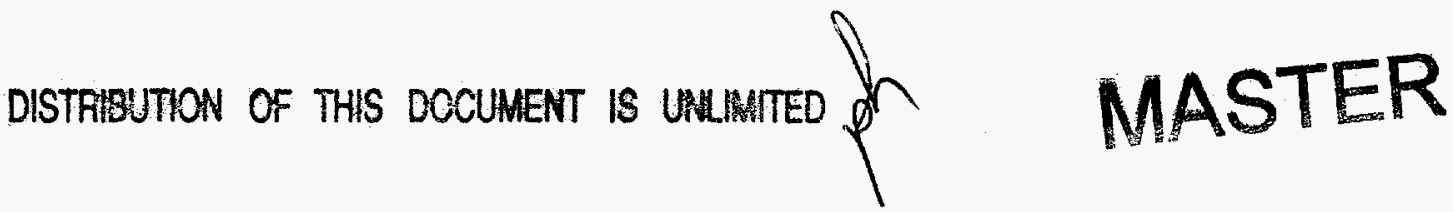

\begin{abstract}
NOTICE
This report was prepared as an account of work sponsored by the United States Government. Neither the United States, nor the United States Department of Energy, nor any of their employees, nor any of their contractors, subcontractors, or their employees, makes any warranty, express or implied, or assumes any legal liability or responsibility for the accuracy, completeness or usefulness of any information, apparatus, product or process disclosed, or represents that its use would not infringe privately owned rights.
\end{abstract}




\section{DISCLAMMER}

This report was prepared as an account of work sponsored by an agency of the United States Government. Neither the United States Government nor any agency thereof, nor any of their employees, makes any warmanty, express or implied, or assumes any legal liability or responsibility for the aceuracy, completeress, or usefuiness of any information, apparatus, product, or process disclosed, or represents that its use would not infringe privately owned rights. Reference berein to any specific commercial product, process, or service by trade aame, trademart, inanufacturet, or otherwise does not necessarily constitute or imply its endorsement, recommendation, or favoring by the United States Government or any ageacy thereof. The views and opinions of authors expressed herein do not necessarily state or reflect those of the United States Government or any agency thereof. 


\section{DISCLAIMER}

Portions of this document may be illegible in electronic image products. Images are produced from the best available original document. 


\title{
Lattice-Matched Epitaxial GaInAsSb/GaSb Thermophotovoltaic Devices*
}

\author{
C.A. Wang, H.K. Choi, G.W. Turner, D.L. Spears, and M.J. Manfra, \\ Lincoln Laboratory, Massachusetts Institute of Technology, Lexington, MA 02173-9108
}

\author{
G.W. Charache \\ Lockheed Martin, Inc., Schenectady, NY 12301
}

\begin{abstract}
The materials development of $\mathrm{Ga}_{1-\mathrm{x}} \mathrm{In}_{\mathrm{x}} \mathrm{As}_{\mathrm{y}} \mathrm{Sb}_{1-\mathrm{y}}$ alloys for lattice-matched thermophotovoltaic (TPV) devices is reported. Epilayers with cutoff wavelength 2 - 2.4 $\mu \mathrm{m}$ at room temperature and lattice-matched to GaSb substrates were grown by both low-pressure organometallic vapor phase epitaxy and molecular beam epitaxy. These layers exhibit high optical and structural quality. For demonstrating lattice-matched thermophotovoltaic (TPV) devices, p- and $n$ - type doping studies were performed. Several TPV device structures were investigated, with variations in the base/emitter thicknesses and the incorporation of a high bandgap GaSb or AlGaAsSb window layer. Significant improvement in the external quantum efficiency is observed for devices with an $\mathrm{AlGaAsSb}$ window layer compared to those without one.
\end{abstract}

\section{INTRODUCTION}

Recent developments of thermophotovoltaic (TPV) systems are based on thermal sources which operate in the temperature range $1100-1500 \mathrm{~K}$ [1]. For high conversion efficiency, the cutoff wavelength of the photovoltaic cell should closely match the peak in emissive power of the thermal source, which for this temperature range corresponds to $1.9-2.6 \mu \mathrm{m}$. Consequently, optimized cells

* This work was sponsored by the Department of Energy under AF contract No. F19628-95-C0002. The opinions, interpretations, conclusions and recommendations are those of the author and are not necessarily endorsed by the United States Air Force. 
will be based on low-bandgap semiconductor materials. For example, InGaAs grown on InP substrates has been pursued [2,3]. However, the alloy composition that satisfies this wavelength range is lattice mismatched to the InP substrate, and defect filtering schemes must be incorporated to reduce crystalline defects. In spite of this limitation, TPV devices have exhibited external quantum efficiency (QE) as high as $50 \%$ at $2 \mu \mathrm{m}[3]$.

An alternative low-bandgap materials system is the $\mathrm{Ga}_{1-\mathrm{x}} \mathrm{In}_{\mathrm{x}} \mathrm{As}_{\mathrm{y}} \mathrm{Sb}_{1-\mathrm{y}}$ quaternary alloy which has the advantage of being lattice matched to either $\mathrm{GaSb}$ or InAs substrates. The energy gap is dependent primarily on the In content, while As determines the lattice matching. Growth on GaSb substrates is preferred over InAs substrates due to thermodyamic considerations [4], electronic band structure[5], and mechanical stability [6]. Thermodynamically stable alloys with a cutoff wavelength of $2.39 \mu \mathrm{m}$ have been grown on $\mathrm{GaSb}$ by liquid phase epitaxy (LPE) [7]. Therefore, the $\mathrm{Ga}_{1-\mathrm{x}} \mathrm{In}_{\mathrm{x}} \mathrm{As}_{1-\mathrm{y}} \mathrm{Sb}_{\mathrm{y}}$ alloys are of particular interest for TPV systems. Recently, GaInAsSb TPV devices grown by LPE and molecular beam epitaxy (MBE) have been demonstrated, and external QE exceeding $40 \%$ at $2 \mu \mathrm{m}$ has been obtained [6,8-9].

In this paper, we report the growth of $\mathrm{Ga}_{1-\mathrm{x}} \mathrm{In}_{\mathrm{x}} \mathrm{As}_{\mathrm{y}} \mathrm{Sb}_{1-\mathrm{y}}$ alloys lattice matched to GaSb substrates by both organometallic vapor phase epitaxy (OMVPE) and MBE. Doping studies were performed, and the electrical, optical, and structural properties of these alloys grown using the different techniques are presented and compared. P-on- $\mathrm{Ga}_{1-\mathrm{x}} \mathrm{In}_{\mathrm{x}} \mathrm{As}_{\mathrm{y}} \mathrm{Sb}_{1-\mathrm{y}}$ devices were grown on $\mathrm{GaSb}$ substrates and evaluated. The effects of base/emitter thickness, surface passivation layer, and higher bandgap $\mathrm{AlGaAsSb}$ window layers on the quantum efficiency are presented.

\section{EPITAXIAL GROWTH AND CHARACTERIZATION}

For OMVPE growth, $\mathrm{Ga}_{1-\mathrm{x}} \mathrm{In}_{\mathrm{x}} \mathrm{Asy} \mathrm{Sb}_{1-\mathrm{y}}$ epilayers were grown on (100) Te-doped GaSb or semi-insulating (SI) GaAs substrates misoriented $2^{\circ}$ toward (110) or $6^{\circ}$ toward (111)B. A vertical rotating-disk reactor with $\mathrm{H}_{2}$ carrier gas at a flow rate of $10 \mathrm{slpm}$ and reactor pressure of 150 Torr was used [10]. All organometallic sources including solution trimethylindium (TMIn), 
triethylgallium (TEGa), tertiarybutylarsine (TBAs), and trimethylantimony (TMSb) were used with diethyltellurium (DETe) $\left(50 \mathrm{ppm}\right.$ in $\left.\mathrm{H}_{2}\right)$ and dimethylzinc (DMZn) (1000 ppm in $\mathrm{H}_{2}$ ) as $\mathrm{n}$ - and p-type doping sources, respectively [11]. The total group III mole fraction was typically 3.5 to $4 \times 10^{-4}$ which resulted in a growth rate of $-2.7 \mu \mathrm{m} / \mathrm{h}$. The V/II ratio was typically 1.1 1.3. The growth temperature ranged from $525-575^{\circ} \mathrm{C}$. AlGaAsSb latticematched to GaSb substrates was grown with tritertiarybutylaluminum (TTBAl), TEGa, TBAs, and TMSb as previously described [12].

For MBE growth, epilayers were grown on (100) Te-doped GaSb or SI GaAs substrates in a solid-source EPI Gen II system. Conventional effusion cells were used to provide $\mathrm{Ga}$, In, and $\mathrm{Sb}_{4}$ fluxes, and a valved As cracker to provide As2 as described previously [13]. The growth temperature was 500 to $510^{\circ} \mathrm{C}$, and the growth rate was $\sim 1 \mu \mathrm{m} / \mathrm{h}$. Be was used as the p-type dopant, and GaTe as the n-type dopant.

The surface morphology was examined using Nomarski contrast microscopy. Double-crystal $x$-ray diffraction (DCXD) was used to measure the degree of lattice mismatch to GaSb substrates. Photoluminescence (PL) was measured at 4 and $300 \mathrm{~K}$ using a cooled $\mathrm{PbS}$ detector. Electrical properties were obtained from Hall measurements based on the van der Pauw method. The composition of epilayers was determined from DCXD splitting, the peak emission in PL spectra, and the energy gap dependence on composition based on the binary bandgaps [14]:

$0.62 x y^{2}$,

$$
E(x, y)=0.726-0.961 x-0.501 y+0.08 x y+0.415 x^{2}+1.2 y^{2}+0.021 x^{2} y-
$$

where $y=0.867 x /(1-0.048 x)$, the condition for lattice matching to GaSb.

\section{GROWTH RESULTS}

For OMVPE growth, the sensitivity of As incorporation (which controls

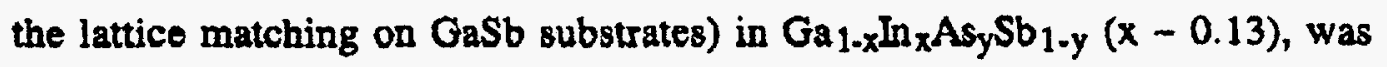
established by growing epilayers with various TBAs vapor phase concentration ratios, $y_{v}=[$ TBAs $] /($ TBAs $\left.]+[T M S b]\right)$. The results, Figure 1, show that the lattice mismatch varies linearly with little deviation as a function of $\mathrm{y}_{\mathrm{V}}$, 
indicating that TBAs provides excellent controllability of lattice-matching conditions. Similar control of lattice matching was obtained for epilayers grown by MBE.

The surface morphology of lattice-matched GaInAsSb epilayers grown by OMVPE on (100) substrates with a $2^{\circ}$ toward (110) misorientation was mirror-like to the eye, but for $\mathrm{x}>0.1$, exhibited a slight texture under Nomarski contrast. For epilayers grown on substrates with a $6^{\circ}$ toward (111)B misorientation, the surface was mirror smooth. The morphology was mirror smooth for all MBE-grown epilayers. Cross-hatching was observed for all layers with a lattice mismatch $>5 \times 10^{-3}$. Figure 2 shows the DCXD scan for a $2-\mu \mathrm{m}$ thick $\mathrm{Ga}_{0.9} \mathrm{In}_{0.1} \mathrm{As}_{0.08} \mathrm{Sb}_{0.92}$ layer. A narrow full width at half-maximum (FWHM) of 21 arc sec, which is comparable to 22 arc sec for the GaSb substrate, indicates the excellent structural quality of this layer. The x-ray splitting of 39 arc sec corresponds to a lattice mismatch of $3 \times 10^{-4}$. For lattice-matched epilayers, the DCXD scans are similar whether the layers are grown by OMVPE or MBE.

The optical quality of $\mathrm{Ga}_{1-\mathrm{x}} \mathrm{In}_{\mathrm{x}} \mathrm{As} \mathrm{sb}_{1-\mathrm{y}}$ epilayers was evaluated by comparing the FWHM of PL spectra measured at $4 \mathrm{~K}$. Figure 3 summarizes the results for epilayers grown by OMVPE and MBE. The composition of epilayers was varied to cover the $300 \mathrm{~K}$ energy range $0.55-0.72 \mathrm{eV}$, corresponding to 2.4 $1.9 \mu \mathrm{m}$. In general, the FWHM values are comparable for layers grown by OMVPE and MBE for $4 \mathrm{~K}$ PL peak energy $E_{\mathrm{pk}}>0.58 \mathrm{eV}$. For lower $\mathrm{E}_{\mathrm{pk}}$, FWHM values are slightly larger for layers grown by OMVPE. Also shown for comparison are data for layers grown by LPE [15] and OMVPE [16].

The electrical properties were measured at $300 \mathrm{~K}$ for nominally undoped $\mathrm{Ga}_{0.87} \mathrm{In}_{0.13} \mathrm{As}_{0.12} \mathrm{Sb}_{0.88}$ layers grown on SI GaAs substrates. This composition corresponds to a cutoff wavelength of $2.2 \mu \mathrm{m}$ at $300 \mathrm{~K}$. Since the lattice mismatch between $\mathrm{Ga}_{1-\mathrm{x}} \mathrm{In}_{\mathrm{x}} \mathrm{As}_{1-\mathrm{y}} \mathrm{Sb}_{\mathrm{y}}$ (lattice matched to $\mathrm{GaSb}$ ) and $\mathrm{GaAs}$ is $8 \%$, growth was first initiated with a GaSb buffer layer. For layers grown by OMVPE at $550^{\circ} \mathrm{C}$, nominally undoped epilayers are $\mathrm{p}$ type with a typical hole concentration of $5-8 \times 10^{15} \mathrm{~cm}^{-3}$ and hole mobility $450-580 \mathrm{~cm}^{2} / \mathrm{V}$-s. Nominally undoped GaInAsSb layers grown by MBE are $\mathrm{p}$ type with a hole concentration of $2 \times 10^{16} \mathrm{~cm}^{-3}$ and mobility of $\sim 300 \mathrm{~cm}^{2} / \mathrm{V}$-s. 
The $300 \mathrm{~K}$ electrical properties of $\mathrm{n}^{-}$and $\mathrm{p}$-doped $\mathrm{Ga}_{0.87} \mathrm{In}_{0.13} \mathrm{As}_{0.12} \mathrm{Sb}_{0.88}$ layers grown by OMVPE and MBE are summarized in Figures 4 and 5, respectively. Although the results for MBE-grown layers are somewhat limited, similar electrical characteristics are observed. For OMVPE layers, the electron concentration ranged from $2.3 \times 10^{17}$ to $2.3 \times 10^{18} \mathrm{~cm}^{-3}$, with corresponding mobility values of 5208 and $2084 \mathrm{~cm}^{2} / \mathrm{V}-\mathrm{s}$, respectively. The hole concentration ranged from $4.4 \times 10^{16}$ to $1.7 \times 10^{18} \mathrm{~cm}^{-3}$ with corresponding mobility values of 419 and $180 \mathrm{~cm}^{2} / \mathrm{V}$-s, respectively.

\section{DEVICE STRUCTURES AND FABRICATION}

Several different TPV structures were grown for comparison. The basic structure consists of an n-GaInAsSb base layer and p-GaInAsSb emitter layer grown on a GaSb substrate. Variations to the structure included a variation in base/emitter layer thicknesses and incorporation of an $\mathrm{AlGaAsSb} / \mathrm{GaSb}$ window layer. Device structures grown by OMVPE were on (100) GaSb substrates with either $2^{\circ}$ toward (110) or $6^{\circ}$ toward (111)B misorientation, while structures grown by MBE were on exactly (100) GaSb substrates. Table 1 summarizes the device structure, substrate orientation, 300K PL peak emission, and lattice mismatch $\Delta \mathrm{a} / \mathrm{a}$. The doping level of the $\mathrm{p}$-GaInAsSb emitter layer was designed at $\sim 2 \times 10^{17} \mathrm{~cm}^{-3}$, since our earlier studies on test structures indicated that for structures with $\mathrm{p} \leq 2 \times 10^{17} \mathrm{~cm}^{-3}$, the diode ideality factor ranged from $1.1-1.3$ in the current density of $0.01-1 \mathrm{~A} / \mathrm{cm}^{2}$. An increase in the ideality factor was observed for diodes fabricated from structures with higher hole concentrations, which may be related to tunneling [8].

Mesa diodes, 0.5 and $1 \mathrm{~cm}^{2}$, were fabricated by a conventional photolithographic process. A single 1-mm-wide central busbar connected to 10$\mu \mathrm{m}$ wide grid lines spaced $100 \mu \mathrm{m}$ apart was used to make electrical contact to the front surface. Ohmic contacts to $\mathrm{p}$ - and $\mathrm{n}-\mathrm{GaSb}$ were formed by depositing $\mathrm{Ti} / \mathrm{Pt} / \mathrm{Au}$ and $\mathrm{Au} / \mathrm{Sn} / \mathrm{Ti} / \mathrm{Pt} / \mathrm{Au}$, respectively, and alloying at $300^{\circ} \mathrm{C}$. Mesas were formed by wet chemical etching to a depth of $5 \mu \mathrm{m}$. No anti-reflection coatings were deposited on these test devices. 


\section{DEVICE RESULTS}

The external quantum efficiency (QE) as a function of wavelength for devices OM-379, OM-459, OM-462, and OM-463 are shown in Figure 6. The value of $\Delta \mathrm{a} / \mathrm{a}$ of these structures is less than $2 \times 10^{-3}$. The highest $\mathrm{QE}$ near the bandedge is observed for OM-463 with a $3-\mu \mathrm{m}$-thick emitter layer $/ 1-\mu \mathrm{m}$-thick base layer, which results because of the higher minority carrier diffusion length in p-type GaInAsSb compared to n-type GaInAsSb. However, at shorter wavelengths, the $\mathrm{QE}$ of OM-463 is lower than OM-462 which consists of $1-\mu \mathrm{m}-$ thick emitter layer $/ 3-\mu \mathrm{m}$-thick base layer. Since carriers are predominantly generated in the base layer for OM-462, this result suggests that these GaInAsSb devices are highly susceptible to surface recombination. The highest $\mathrm{QE}$ at wavelengths below $1.6 \mu \mathrm{m}$ is measured for OM-379 which has a GaSb window layer. In general, the performance of devices grown on (100) $2^{\circ}$ toward (110) substrates are inferior to those grown on (100) $6^{\circ}$ toward (111)B substrates. The QE of TPV devices grown by MBE (3- $\mu \mathrm{m}$-thick emitter layer/1- $\mu \mathrm{m}$-thick base layer) is similar to the results measured for OMVPE-grown devices.

Figure 7 shows the $\mathrm{QE}$ as a function of wavelength for OM-544 that consists of a $3-\mu \mathrm{m}$-thick emitter layer, $1-\mu \mathrm{m}$-thick base layer, and latticematched $\mathrm{Al}_{0.25} \mathrm{Ga}_{0.75} \mathrm{As}_{0.02} \mathrm{Sb}_{0.98} / \mathrm{GaSb}$ window layer. Higher bandgap window layers are often incorporated to improve the performance GaAs and InP solar cells [17]. For OM-544 with $\Delta \mathrm{a} / \mathrm{a}<1 \times 10^{-3}$, the QE is nearly $60 \%$ over the whole wavelength range from $1.2-2.0 \mu \mathrm{m}$, which is dramatically higher than devices shown in Figure 6 without the AlGaAsSb window layer, higher than has been previously reported for GaInAsSb/GaSb TPV devices [6,8-9], and approaching the $\sim 70 \%$ limit for uncoated devices. Compared to OM-544, the $\mathrm{QE}$ is slightly lower by about $5 \%$ for OM-543 with $\Delta \mathrm{a} / \mathrm{a}=2.5 \times 10^{-3}$ and lowest for OM-542 with $\Delta \mathrm{a} / \mathrm{a}=5 \times 10^{-3}$, indicating that structural defects affect the performance of these devices.

The $300 \mathrm{~K}$ photoluminescence spectra of TPV structures with and without the AlGaAsSb window layer are shown in Figure 8. The PL efficiency is more than 5 times higher for the structure with the window layer. Since carriers are generated near the surface in these PL experiments (excitation source is $647 \mathrm{~nm}$ ), 
these results indicate that the $\mathrm{AlGaAsSb}$ is epecially effective in passivating the surface of the underlying GaInAsSb and effectively reduces the surface recombination velocity. Furthermore, standard calculations [18] of external QE suggest that the surface recombination velocity may be reduced by several orders of magnitude with the AlGaAsSb window layer and that the minority electron diffusion length in our lattice-matched GaInAsSb is about $5 \mu \mathrm{m}$. The $\mathrm{QE}$ is comparable to lattice-mismatched $\mathrm{InGaAs} / \mathrm{InP}$ devices, which had a maximum $\mathrm{QE}$ of $65 \%$ at $1.2 \mu \mathrm{m}$ and dropped off to $53 \%$ at $2.0 \mu \mathrm{m}$ [3]. Further characterization of GaInAsSb/AlGaAsSb/GaSb devices should be performed to assess the potential of this materials system for TPV systems.

\section{CONCLUSIONS}

High-quality GaInAsSb epilayers were grown lattice matched to $\mathrm{GaSb}$ substrates by OMVPE and MBE. The use of a higher bandgap AlGaAsSb window layer is particularly effective in increasing the external $\mathrm{QE}$ by reducing surface recombination velocity, and results in overall improved performance especially at shorter wavelengths. External QE over $55 \%$ between $1.2-2 \mu \mathrm{m}$ has been measured. The present results suggest that GaInAsSb materials system is promising for high performance TPV systems with source temperatures operating $1100-1500 \mathrm{~K}$.

\section{ACKNOWLEDGMENTS}

The authors gratefully acknowledge D.R. Calawa, J.W. Chludzinski, M.K. Connors, C.D. Hoyt, P.M. Nitishin, D.C. Oakley, R.J. Poillucci, and V. Todman-Bams for technical assistance, K.J. Challberg for manuscript editing, and B-Y. Tsaur for continued support and encouragement. 


\section{REFERENCES}

1. J.P. Benner, T.J. Coutts, and D.S. Ginley, 2nd NREL Conference on the Thermophotovoltaic Generation of Electricity, AIP Conf. Proc. 358, Woodbury, NY, 1995.

2. Wanlass, M.W., Ward, J.S., Emery, K.A., Al-Jassim, M.M., Jones, K.M. and Coutts, T.J., "Ga ${ }_{\mathrm{X}} \mathrm{In}_{1-\mathrm{x}}$ As thermophotovoltaic converters," Solar Energy Mater. and Solar Cells 41/42, 405-417 (1996).

3. Wojtczuk, S., Colter, P., Charache, G., and Campbell, B., "Production data on $0.55 \mathrm{eV}$ InGaAs thermophotovoltaic cells," Proc. 25th IEEE

Photovoltaic Specialist Conference, p. 77-80 (1996).

4. Cherng, M.J., Jen, H.R., Larsen, C.A., Stringfellow, G.B., Lundt, H. and Taylor, P.C., "MOVPE growth of GaInAsSb," J. Cryst. Growth 77, 408417 (1986).

5. Milnes, A.G. and Polyakov, A.Y., "Indium arsenide: a semiconductor for high speed and electro-optical devices," Mater. Sci. and Engin., B18, 237259 (1993).

6. Uppal, P.N., Charache, G., Baldasaro, P.F., Campbell, B.C., Loughin, S., Svensson, S., and Gill, D., "MBE growth of GaInAsSb p/n junction diodes for thermophotovoltaic applications," to appear J. Cryst. Growth.

7. Tournie, E., Pitard, F., and Joullie, A., "High temperature liquid phase epitaxy of (100) oriented GaInAsSb near the miscibility gap boundary," J. Cryst. Growth 104, 683-694 (1990).

8. Charache, G.W., Egley, J.L., Danielson, L.R., DePoy, D.M., Baldasaro, P.F., Campbell, B.C., Hui, S., Frass, L.M., Wojtczuk, S.J., "Current status of low-temperature radiator thermophotovoltaic devices," Proc. 25th IEEE Photovoltaic Specialist Conference, p. 137-140 (1996).

9. Shellenbarger, Z.A., Mauk, M.G., DiNetta, L.C. and Charache, G.W., "Recent progress in InGaAsSb/GaSb TPV devices," Proc. 25th IEEE Photovoltaic Specialist Conference, p. 81-84 (1996).

10. Wang, C.A., Patnaik, S., Caunt, J.W., and Brown, R.A., "Growth characteristics of a vertical rotating-disk OMVPE reactor," J. Cryst. Gr. 93, 228-234 (1988).

11. Wang, C.A. and Choi, H.K., "OMVPE Growth of GaInAsSb/AlGaAsSb for Quantum-Well Diode Lasers," to appear J. Electron. Mater.

12. Wang, C.A., "Organometallic Vapor Phase Epitaxial Growth of AlSbbased alloys," J. Cryst. Growth 170, 725-731 (1997). 
13. Turner, G.W., Choi, H.K., Calawa, D.R., Pantano, J.V., and Chludzinski, J.W., "Molecular-beam growth of high-performance midinfrared diode lasers," J. Vac. Sci. Technol. B 12, 1266-1268 (1994).

14. DeWinter, J.C., Pollock, M.A., Srivastava, A.K., and Zyskind, J.L., "Liquid phase epitaxial $\mathrm{Ga}_{1-\mathrm{x}} \mathrm{In}_{\mathrm{x}} \mathrm{Ass}_{\mathrm{y}} \mathrm{Sb}_{1-\mathrm{y}}$ lattice-matched to (100) $\mathrm{GaSb}$ over the 1.71 to $2.33 \mu \mathrm{m}$ wavelength range," J. Electron. Mater. 14, 729-747 (1985).

15. Tournie, E., Lazzari, J.-L., Pitard, F., Alibert, C., Joullie, A., and Lambert, B, " $2.5 \mu \mathrm{m}$ GaInAsSb lattice-matched to GaSb by liquid phase epitaxy," J. Appl. Phys. 68, 5936-5938 (1990).

16. Sopanen, M., Koljonen, T., Lipsanen, H., and Tuomi, T., "Growth of GaInAsSb using tertiarybutylarsine as arsenic source," J. Cryst. Growth 145, 492-497 (1994).

17. Hovel, H.J., Solar Cells, Semiconductors and Semimetals, Vol. 11, Academic Press, NY, 1975.

18. Moller, H.J., Semiconductors for Solar Cells, Artech House, Inc., Boston, 1993. 


\section{FIGURE CAPTIONS}

Figure 1 Dependence of lattice mismatch of GaInAsSb epilayers grown at $575^{\circ} \mathrm{C}$ by $\mathrm{OMVPE}$ on $\mathrm{GaSb}$ substrates as function of TBAs gas phase concentration.

Figure 2 Double-crystal x-ray diffraction scan of $\mathrm{Ga}_{0.9} \ln _{0.1} \mathrm{As}_{0.08} \mathrm{Sb}_{0.92}$ grown at $575^{\circ} \mathrm{C}$ on $\mathrm{GaSb}$ by $\mathrm{OMVPE}$.

Figure 3 Full width at half-maximum of photoluminescence spectra measured at 4K of GaInAsSb layers grown on GaSb substrates by OMVPE and MBE.

Figure 4 Electrical properties measured at $300 \mathrm{~K}$ of $\mathrm{n}-\mathrm{Gap}_{0.87} \mathrm{In}_{0.13} \mathrm{As} 0.12 \mathrm{Sb} 0.88$ grown by OMVPE and MBE.

Figure 5 Electrical properties measured at $300 \mathrm{~K}$ of $\mathrm{p}-\mathrm{Ga}_{0.87} \mathrm{In}_{0.13} \mathrm{As}_{0.12} \mathrm{Sb}_{0.88}$ grown by OMVPE and MBE.

Figure 6 External quantum efficiency of TPV devices described in Table 1.

Figure 7 External quantum efficiency of TPV devices with AlGaAsSb window layer.

Figure 8 Photoluminescence spectra of TPV devices with and without $\mathrm{AlGaAsSb}$ window layer. 


\begin{tabular}{|c|c|c|c|c|c|c|c|}
\hline Run & $n-G a I n A s S b(\mu m)$ & p-GaInAsSb $(\mu m)$ & p-AJGaAsSb(um) & $\mathrm{p}-\mathrm{GaSh}(\mu \mathrm{m})$ & orientation & 300K PL peak emission $(\mu \mathrm{m})$ & $\Delta \mathrm{a} a(\mathrm{x} 10-3)$ \\
\hline OM-379 & 3 & 0.2 & 0 & 0.05 & $(100) 2(110)$ & 2.15 & o \\
\hline OM-459 & 3 & 1 & 0 & 0 & $(100) 2(110)$ & 2.24 & 2 \\
\hline OM-462 & 3 & 1 & 0 & $\mathbf{0}$ & $(100) 6(111) \mathrm{B}$ & 2.24 & 1 \\
\hline$O M-463$ & 1 & 3 & 0 & 0 & $(100) 6(111) B$ & 2.24 & 1.5 \\
\hline OM-542 & 1 & 3 & 0.1 & 0.025 & (100) $6(111) \mathrm{B}$ & 2.26 & 5 \\
\hline OM-543 & 1 & 3 & 0.1 & 0.025 & $(100) 6(111) B$ & 2.26 & 25 \\
\hline OM-544 & 1 & 3 & 0.1 & 0.025 & $(100) 6(111) B$ & 2.26 & 0.6 \\
\hline MBE-041 & 1 & 3 & 0 & 0 & (100)- & 2.14 & 1 \\
\hline
\end{tabular}




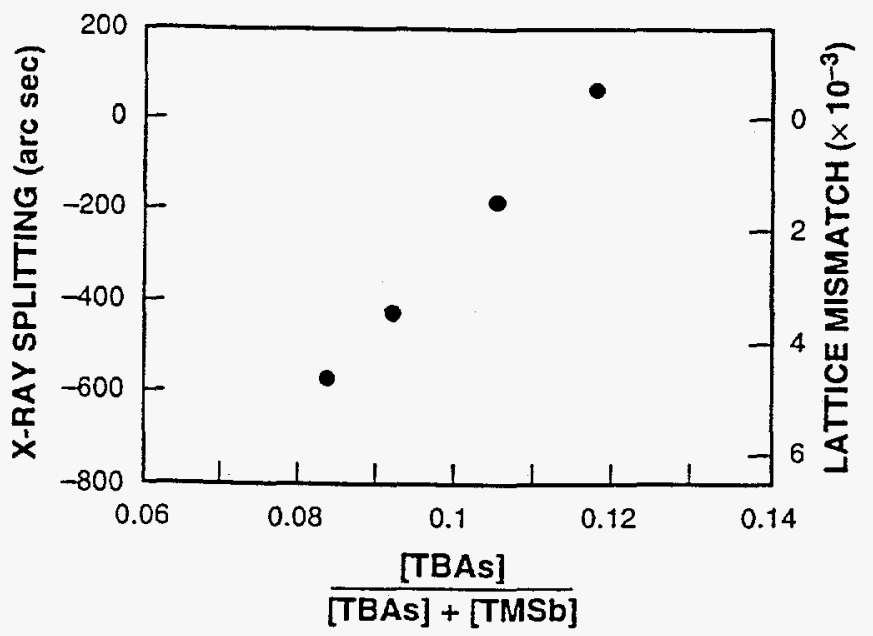

Figure 1

$294395-8$ 


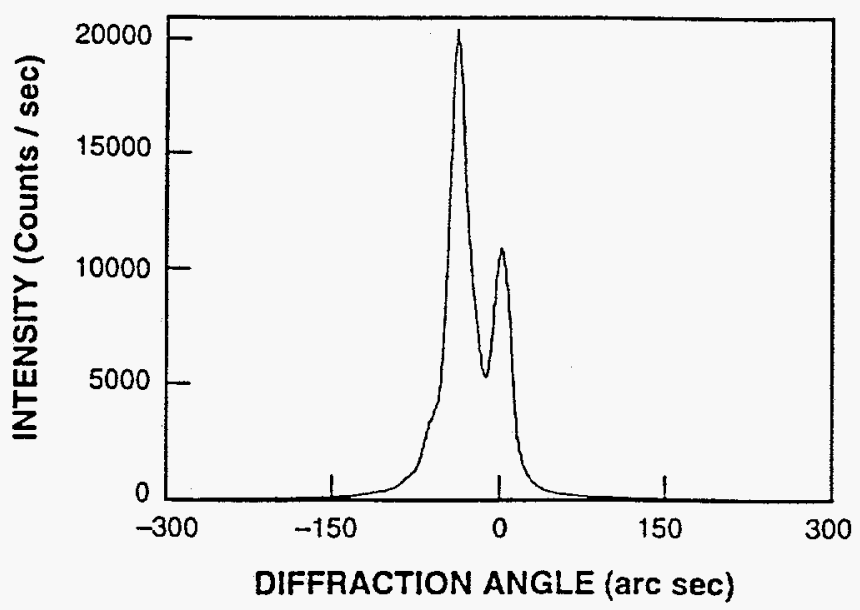

Figure 2

294395-1 


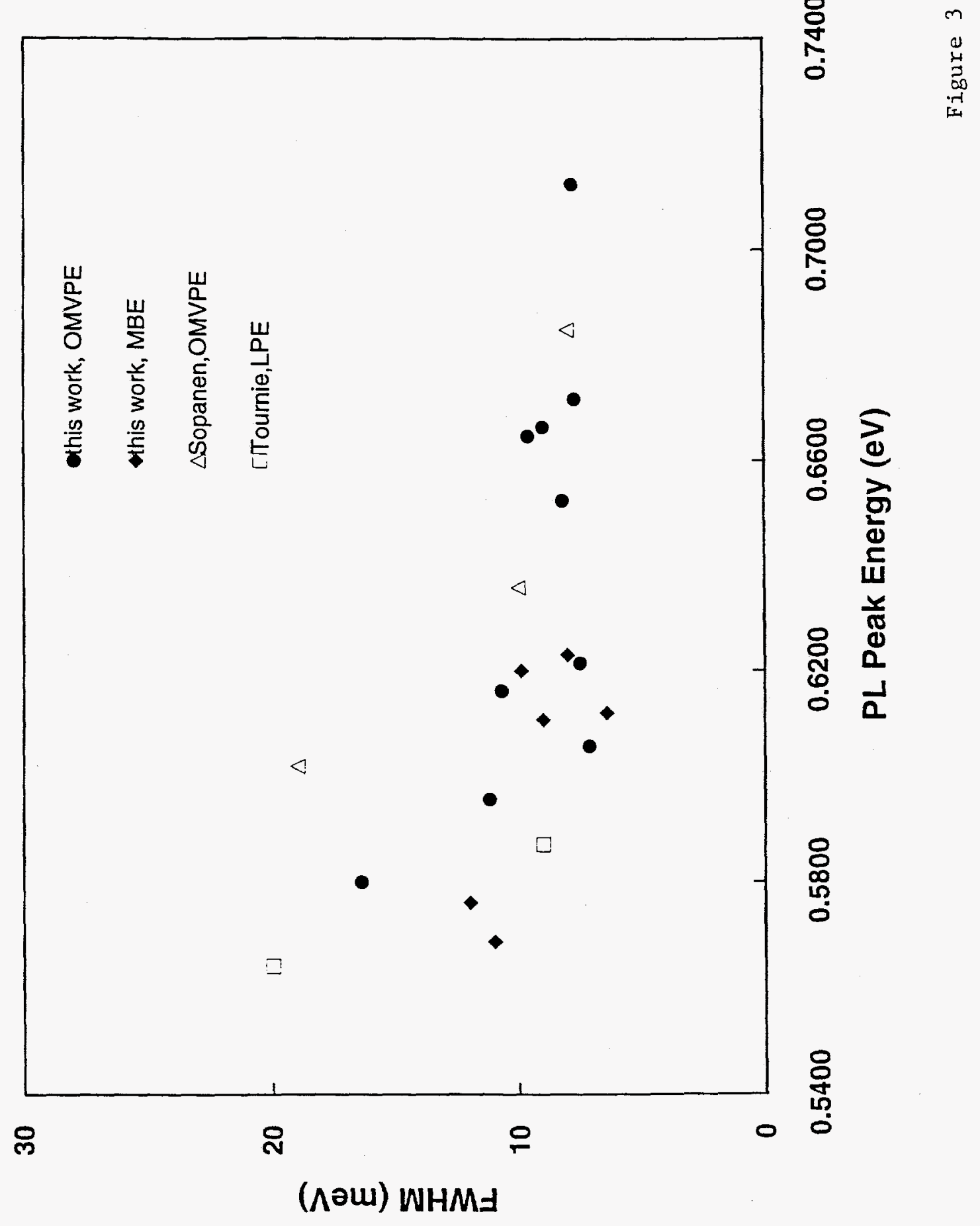




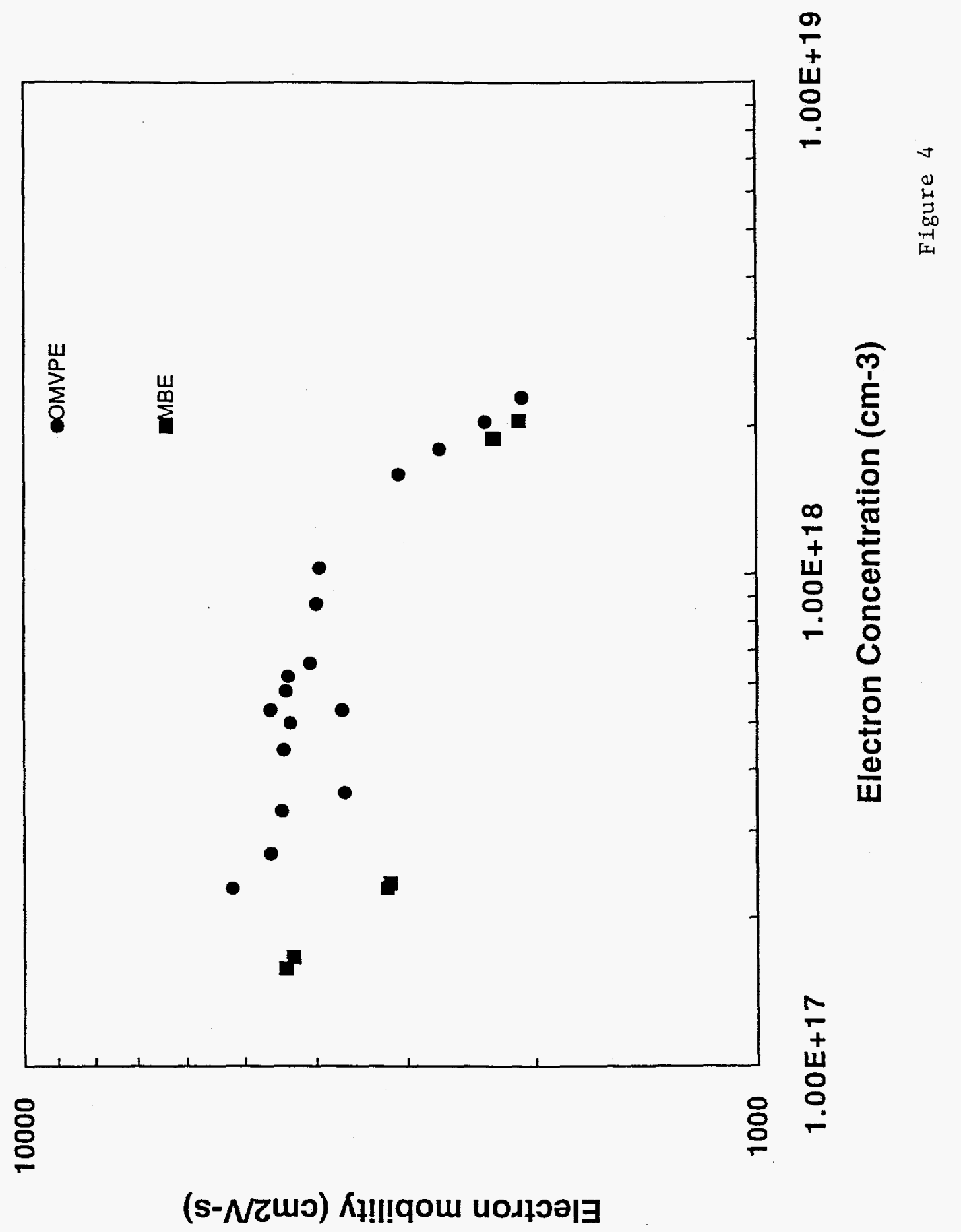




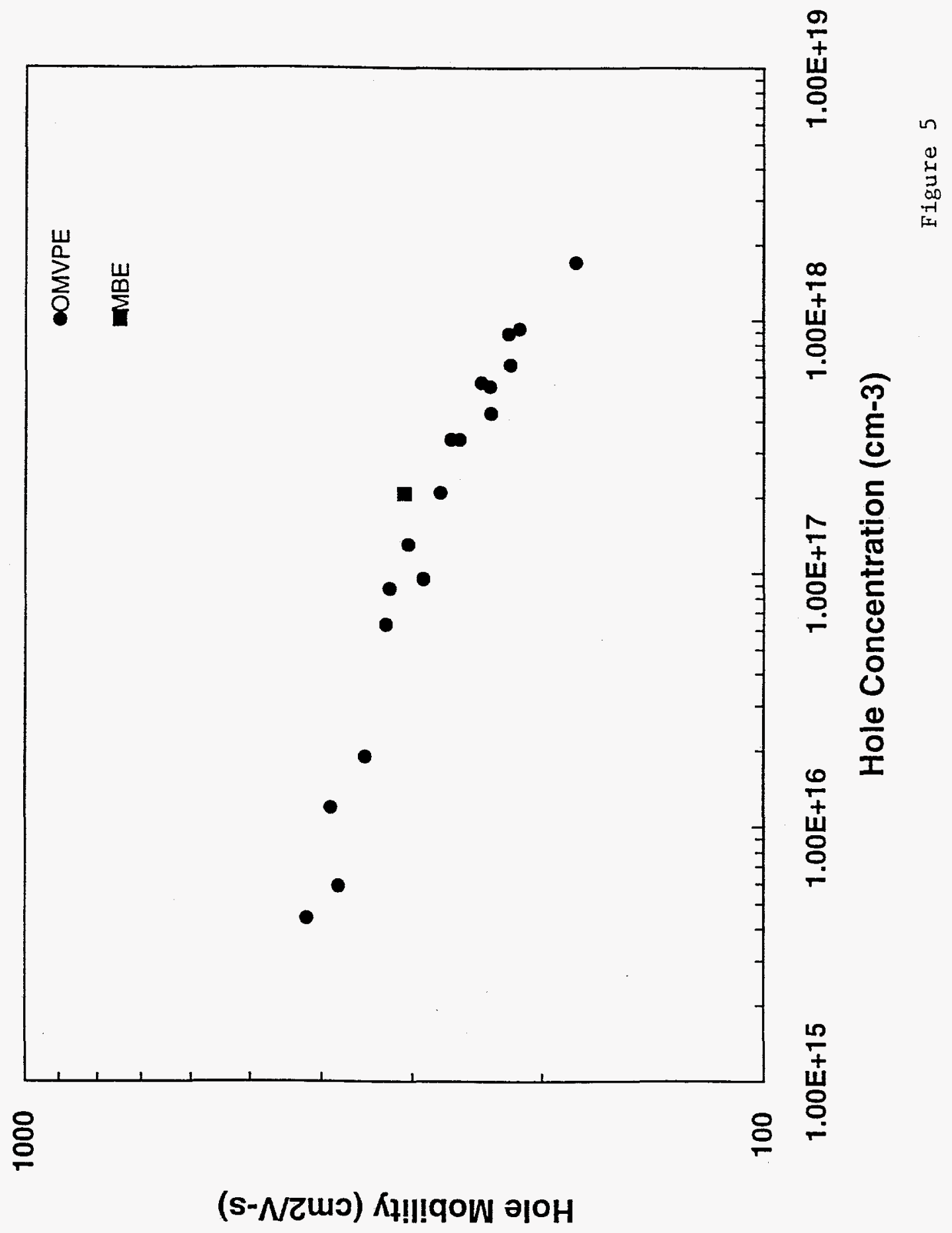




\section{Quantum Efficiency of Lincoln Laboratory Cells}

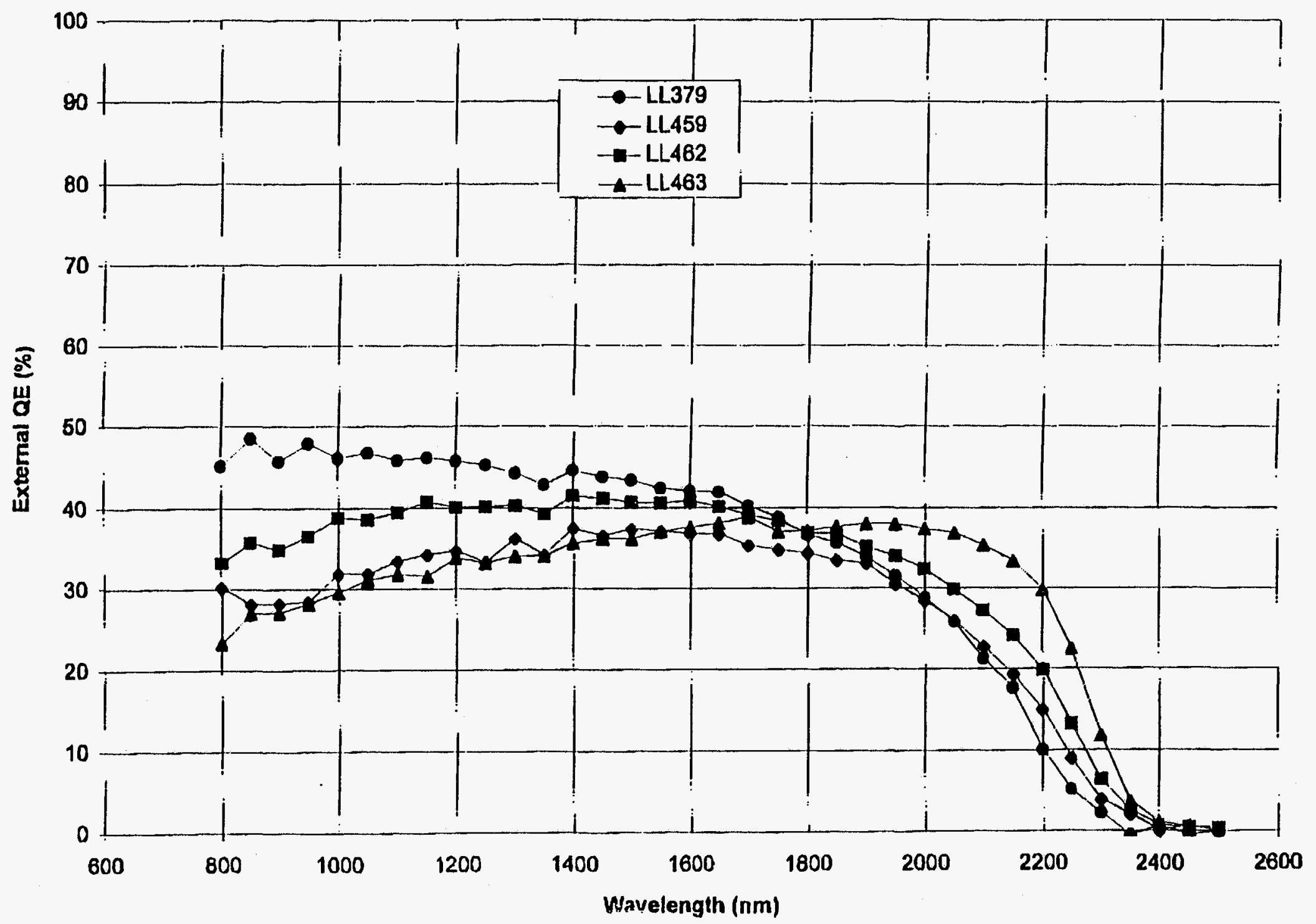

Figure 6 


\section{External Quantum Efficiency (\%)}

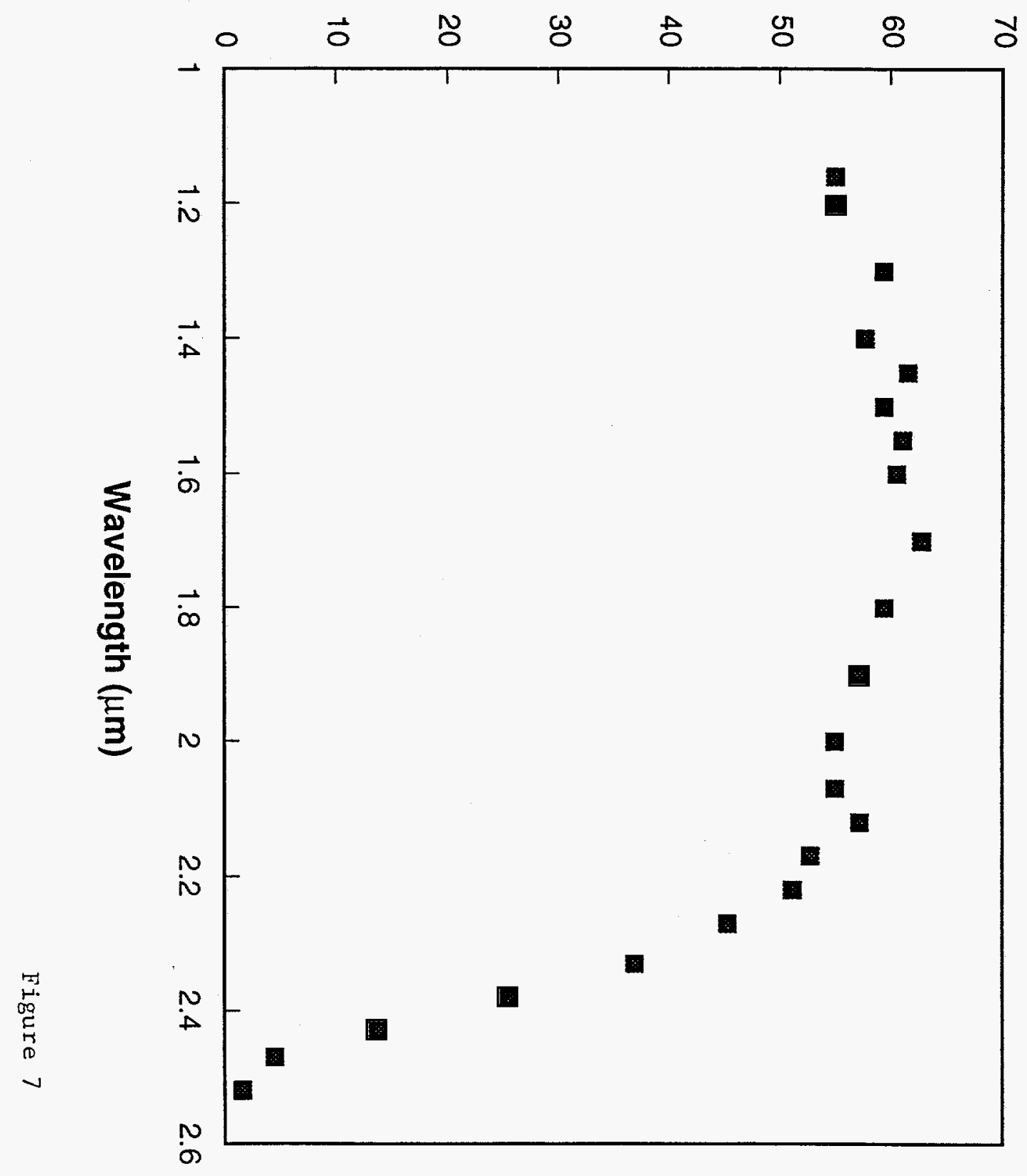




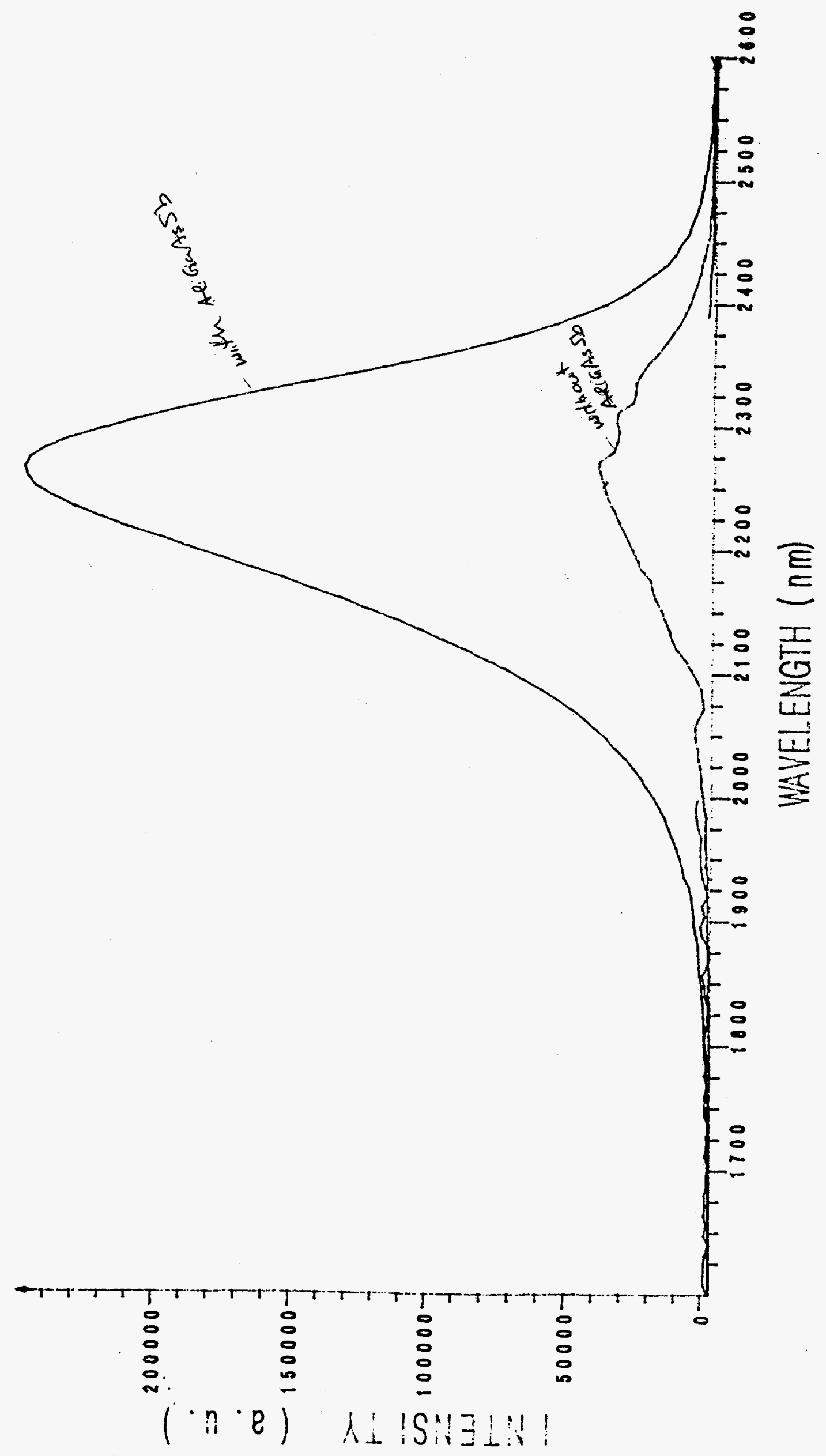

